\title{
MEMAHAMI KORUPSI DI DAERAH PASCA DESENTRALISASI: BELAJAR DARI EMPAT STUDI KASUS ${ }^{1}$
}

\section{UNDERSTANDING CORRUPTION AT LOCAL LEVEL POST DECENTRALIZATION: EVIDENCE FROM FOUR CASE STUDIES}

\section{BUDI SETIYONO}

\begin{abstract}
Abstrak
Sejak masa reformasi dan kebijakan desentralisasi dilaksanakan, banyak sekali pejabat daerah (politisi dan birokrat) yang dipenjara karena tersangkut kasus korupsi. Hal tersebut, walaupun pada satu sisi menunjukkan bukti bahwa usaha pemberantasan korupsi telah menampakkan hasil, akan tetapi pada sisi lain, hal ini menyisakan pertanyaan ironis yang memilukan. Mengapa para pejabat tersebut terjerat kasus korupsi? Apakah mereka kekurangan secara ekonomi sehingga terpaksa harus "mengambil uang negara" bagi dirinya, keluarganya, maupun kelompok tertentu dengan jalan yang tidak legal? Ataukah ini berkaitan dengan konteks sosial politik yang lebih luas yang tidak bisa mereka kendalikan? Artikel ini menunjukkan bahwa penyebab, pola dan modus korupsi yang terjadi di daerah sangat beragam. Selain faktor yang berkaitan dengan moral hazard, korupsi juga berkaitan dengan administrasi pemerintahan yang ruwet, peraturan yang berbelit-belit dan tidak jelas, hierarkhi organisasi yang terlalu kaku, dan persaingan politik dapat menyebabkan seorang pejabat terjebak dalam tindakan yang dipersepsikan sebagai korupsi. Kondisi ini diperparah oleh lemahnya perilaku dan komitmen aparat penegak hukum dalam pemberantasan korupsi. Ketiadaan sistem yang terintegrasi dalam strategi pemberantasan korupsi menyebabkan aksi pemberantasan korupsi tidak berjalan efektif. Oleh karena itu, diperlukan formulasi alternatif kebijakan pemberantasan korupsi yang komprehensif berdasarkan pada asas akuntabilitas dan partisipasi publik.
\end{abstract}

Kata kunci: korupsi pemerintah daerah, kebijakan anti-korupsi, akuntabilitas, governance.

\section{Abstract}

Since 'reformasi movement' and decentralization takes place, a lot of local government officials (politicians and bureaucrats) are jailed due to their involvement in corruption cases. While on the one hand, this may an evidence that corruption eradication efforts have shown positive results, but on the other hand, it leaves ironic heartbreaking questions. Why these officials caught in corruption cases? Are they economically shortage that forced them to illegally "steal the state money" for themself, their family, as well as their patrons? Or is it related to the wider sociopolitical context that they can not control? This paper shows that the causes, patterns and modes of corruption at local level were very diverse. In addition to factors related to moral hazard, corruption is also associated with poor government administration, convoluted and unclear regulations, rigid organizational hierarchy, and political rivalry that can lead to an entrapment of

\footnotetext{
${ }^{1}$ Paper dari hasil Penelitian yang dibiayai oleh DIPA FISIP UNDIP Tahun 2016
} 
official in actions that are perceived as corrupt. These conditions are exacerbated by the weakness of the behavior and commitment of law enforcement agencies in combating corruption. It is urgent, therefore, to develop an integrated system and strategy to increase the effectiveness of corruption eradication. We need to form an a comprehensive policy of combating corruption which is based on the principle of accountability and public participation.

Keywords: local government corruption, anti-corruption measures, accountability, governance.

\section{A. PENDAHULUAN}

Sejak masa reformasi bergulir, dan dilaksanakannya desentralisasi (otonomi daerah) dengan diberlakukannya UU no. 22/1999 tentang Pemerintahan Daerah (dan lebih lanjut diganti UU No. 32 / 2004 dan UU No. 23 / 2014), banyak pejabat daerah yang tersangkut kasus korupsi. Berdasarkan data Kementerian Dalam Negeri, dari tahun 2004 hingga awal tahun 2015 terdapat 343 kepala daerah yang harus menghadapi proses hukum baik di kejaksaan, kepolisian, maupun Komisi Pemberantasan Korupsi (KPK) akibat perkara korupsi, yang sebagian besar karena tersangkut masalah pengelolaan keuangan daerah (Kompas, 4 Februari 2015). Sebagian dari mereka, seperti Ratu Atut Chosiyah (Gubernur Banten), Syamsul Arifin (Gubernur Sumatera Utara), Awang Faruk Ishak (Gubernur Kaltim), Agusrin Najamudin (Gubernur Bengkulu), Fuad Amin (Bupati Bangkalan), Hendi Bundoro dan Siti Nurmarkesi (Bupati Kendal), Rina Iriani (Bupati Karanganyar), dan Amran Batalipu (Bupati Buol), harus mendekam di penjara.

Fakta ini menunjukkan bahwa desentralisasi dapat memiliki konsekweksi yang ambigu: pada satu sisi memungkinkan daerah untuk lebih memiliki kewenangan sehingga flexible dan responsif dalam melakukan pelayanan publik; tapi pada sisi lain, juga menyebabkan para pejabatnya lebih memiliki kesempatan untuk korup. Korupsi oleh pejabat terpilih dan pegawai publik dapat menjadi sumber utama ketidakpuasan publik terhadap pemerintah daerah. Ketika pejabat mengkorup uang dari Anggaran Pendapatan dan Belanja Daerah (APBD), atau meminta uang dari individu atau perusahaan yang berbisnis dengan atau diatur oleh pemerintah daerah, maka akan terjadi kenaikan biaya pemerintah, peraturan yang tak dijalankan, dan secara umum mereduksi kualitas penyelenggaraan pemerintahan. Akhirnya, korupsi menghancurkan harapan pelayanan publik yang baik sebagai tujuan desentralisasi itu sendiri. Indonesia Corruption Watch (ICW) menyebutkan bahwa korupsi di daerah telah menyebabkan 
buruknya kualitas pelayanan publik, khususnya di sektor pendidikan, transportasi dan kesehatan. $^{2}$

Maraknya korupsi di level lokal ini sejalan dengan kondisi serupa di level nasional. Indikasi maraknya praktek korupsi di Indonesia dapat dilihat dari angka persepsi korupsi, misalnya hasil studi yang dilakukan Transparency International. Secara global, dalam sepuluh tahun terakhir, survei Transparency International (TI) menempatkan Indonesia masuk dalam kelompok negara-negara dengan tingkat korupsi tinggi. Dari Corruption Perception Index (CPI) untuk skor 10 (terbersih) hingga skor 0 (terkorup), Indonesia sejak tahun 2001 hingga 2010 selalu dibawah skor 3,0 atau masih tergolong negara sangat korup. Baru pada tahun 2012 tren positif kenaikan skor CPI mulai terlihat. Terbukti dengan perolehan skor Indonesia naik menjadi 32. Pada survey Tranparency International yang terbaru tahun 2015, Indonesia kembali mendapatkan kenaikan skor CPI, yaitu 3,6.

\section{Gambar 1 Skor CPI Indonesia Tahun 2009-2015}

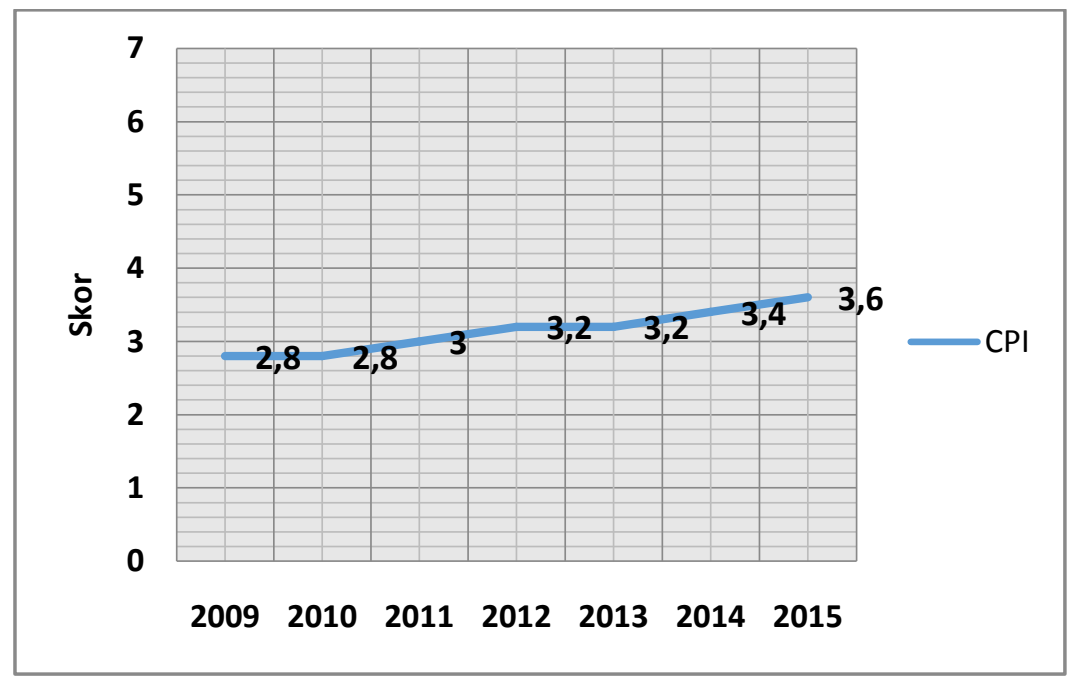

Sumber: Tranparency International (2015)

Penindakan terhadap pejabat daerah yang korup, walaupun pada satu sisi menunjukkan bukti bahwa usaha pemberantasan korupsi telah menampakkan hasil, akan tetapi pada sisi lain, hal ini menyisakan pertanyaan ironis yang memilukan.

\footnotetext{
2 Republika, 25 Februari 2016, ICW: Pelayanan Publik Sektor Paling Rentan Korupsi online http://nasional.republika.co.id/berita/nasional/umum/16/02/25/o32r2n280-icwpelayanan-publik-sektor-paling-rentan-korupsi
} 
Mengapa para pejabat daerah itu terjerat kasus korupsi? Apakah mereka kekurangan secara ekonomi sehingga terpaksa harus menerima suap atau mengambil uang negara bagi dirinya, keluarganya, maupun kelompok tertentu dengan jalan yang tidak legal? Ataukah ini berkaitan dengan kultur yang lebih luas, sehingga terjadinya kasus korupsi para pejabat ini adalah akibat adanya tekanan sosial-politik yang tidak mampu mereka kendalikan? Apakah hal ini disebabkan karena cacatnya sistem politik dan pemerintahan di Indonesia yang menyebabkan mereka terjebak dalam sistem itu? Ataukah hal ini berkaitan dengan masalah moral masing-masing individu pejabat?

Secara teoritik, menurut Bauhr dan Nasiritousi3 ${ }^{3}$, korupsi terjadi karena dua persoalan, yakni karena ada kebutuhan (corruption by need), dan karena sikap rakus untuk menumpuk kekayaan (corruption by greed). Namun demikian, kedua penyebab itu bisa jadi terlalu simplistik. Sebagaimana dikemukakan Sajo ${ }^{4}$, dalam situasi adminisitrasi pemerintahan yang ruwet, keadaan dapat saja memaksa pejabat utuk melakukan korupsi. Dengan kata lain, para pejabat itu secara individu bisa jadi tidak memiliki keinginan untuk bertindak korup, akan tetapi mereka terpaksa terlibat dalam tindakan korupsi karena sistem administrasi tidak memungkinkan mereka bertindak bersih. Peraturan yang berbelit-belit dan tidak jelas, hierarkhi organisasi yang terlalu kaku, dan tugas yang terlalu luas, untuk menyebut beberapa contoh, dapat menyebabkan seorang pejabat terjebak dalam tindakan yang dipersepsikan sebagai korupsi. Dalam kaitan ini, misalnya, perkara korupsi yang menyangkut Syamsul Arifin bisa menjadi studi kasus yang menarik, mengingat Gubernur Sumatera Utara ini dikenal sebagai pribadi yang santun, sederhana dan dekat dengan rakyat. Syamsul adalah pejabat yang memiliki karir cemerlang, yang sebelum menjabat sebagai gubernur, ia menjabat sebagai Bupati Langkat dua periode (1999-2008). Namun nyatanya dia didakwa melakukan korupsi Anggaran Pendapatan dan Belanja Daerah Kabupaten Langkat sehingga merugikan keuangan negara Rp 98,7 miliar.

Ada beberapa jenis korupsi yang terjadi di pemerintahan daerah. Walaupun beberapa diantaranya umum terjadi di semua level pemerintahan, akan tetapi

\footnotetext{
${ }^{3}$ Monica Bauhr and Nagmeh Nasiritousi. Why Pay Bribes? Collective Action and Anti Corruption Efforts, Sweden: University of Gothenburg.

4 Andras Sajo, 'Introduction, Clientelism and Exortion: Corruption in Transition' in Kotkin, S. and A. Sajo (eds), Political Corruption in Transition: A Skeptic's Handbook, Budapest: Central Europe University Press, h. $1-24$
} 
beberapa bentuk lebih dominan terjadi di pemerintah daerah dengan segmen yang lebih besar dari pemerintah pusat. Pemerintahan daerah mungkin lebih rentan terhadap korupsi karena interaksi antara aktor swasta dan pejabat terjadi pada tingkat keintiman yang lebih besar dan dengan frekuensi lebih daripada tingkat nasonal. Bentuk korupsi yang berkaitan dengan penyuapan, pemerasan, penggelapan, nepotisme, patronase dan pemberian hadiah banyak ditemukan dalam sistem pemerintahan daerah. ${ }^{5}$

Apapun yang menjadi penyebab itu, kita perlu mengetahui bagaimana sesungguhnya terjadinya kasus korupsi secara detail untuk menanggulangi agar supaya di kemudian hari tidak ada lagi pejabat yang tersandung masalah korupsi. Oleh karena itu, penelitian ini dilakukan untuk mengidentifikasi penyebab dan modus korupsi, mengenali faktor-faktor kunci yang berpengaruh, serta kemudian menawarkan alternatif kebijakan untuk mengurangi tingkat prevelensi korupsi oleh para pejabat. Akan tetapi, harus dicatat bahwa riset ini mengutamakan analisis persoalan tersebut dari sisi perspektif pelaku, yakni mereka (para pejabat) yang telah ditetapkan oleh pengadilan sebagai terpidana secara berkekuatan hukum tetap (inkracht van gewijsde).

Penelitian ini mengidentifikasi terjadinya kasus korupsi dari beberapa dimensi seperti: 1) Bagaimana asal muasal kasus terjadi; 2) Apakah yang menjadi penyebab dan modus korupsi, apa saja faktor yang berperan; 3) Siapa saja aktor yang terlibat, serta bagaimana mereka berperan dan berhubungan satu sama lain; 4) Bagaimana pola dan proses pelaksanaan korupsi; dan 5) Apa yang harus dilakukan agar kasus serupa tidak terulang.

Peneliti berhasil melakukan pendalaman terhadap empat kasus korupsi di empat daerah (yang karena keterbatasan dana penelitian hanya di Jawa Tengah). Korupsi tersebut melibatkan tersangka utama masing-masing dua walikota, dan dua birokrat senior. Pengumpulan data dalam penelitian ini bertumpu pada metode wawancara mendalam. Secara khusus, peneliti berhasil mewancarai para pelaku utama kasus tersebut, yang kebetulan dipenjara disatu tempat, yakni di Kedungpane Semarang. Disamping itu, untuk memperkaya data yang didapat, penulis juga melakukan

\footnotetext{
${ }^{5}$ Maria Gonzales de Aziz, Reducing Corruption at the local level, World Bank Institute.
} 
wawancara dengan anggota DPR/D, dan para pejabat birokrat (PNS) terkait, dan juga aktifis LSM.

\section{Terminologi Umum Tentang Korupsi}

Secara umum, beberapa teori menggambarkan korupsi sebagai perilaku yang melibatkan penyalahgunaan atau penyalahgunaan jabatan publik, kekuasaan, atau sumber daya untuk kepentingan pribadi. ${ }^{6}$ Literatur kadang membedakan jenis korupsi dalam segmen politik, birokrasi dan ekonomi; namun secara praktis, tiga tipologi ini hanya membedakan dimensi pelaku dari perbuatan yang sama. Semua manifestasi korupsi termotivasi oleh keinginan untuk menggunakan perangkat dan fasilitas dari kekuasaan/kewenangan untuk kepentingan pribadi, keluarga, dan atau kelompok lainnya. Dalam Undang-Undang No. 31 Tahun 1999 Jo Undang-Undang No. 20 Tahun 2001, Bab II Pasal 2, disebutkan bahwa yang dimaksud dengan korupsi adalah: "Setiap orang yang secara melawan hukum melakukan perbuatan memperkaya diri sendiri atau orang lain atau suatu korporasi yang dapat merugikan keuangan negara atau perekonomian negara."7

Sejalan dengan konsepsi ini, Shah \& Schacter berpendapat ${ }^{8}$, korupsi mencakup tiga jenis luas kategori: (a) 'grand corruption', yaitu manakala sejumlah pejabat melakukan pencurian atau penyalahgunaan sumber daya publik secara besar-besaran; (b) 'state capture' atau 'regulatory capture', yaitu kolusi resiprokal yang dilakukan oleh agen-agen pemerintah dan swasta untuk memperoleh keuntungan pribadi; dan (c) 'bureaucratic corruption' atau 'petty corruption', yaitu keterlibatan pejabat publik di level bawah dalam menyalahgunakan jabatan untuk mendapatkan suap atau keuntungan yang kecil.

\footnotetext{
${ }^{6}$ Susan Rose-Ackerman, Corruption: A Study in Political Economy, New York: Academic Press.

${ }^{7}$ Kedua UU tersebut merinci adanya 7 (tujuh) jenis pokok korupsi, yakni: Korupsi yang berkaitan dengan penyalahgunaan keuangan/perekonomian negara (Pasal 2, 3), suap-menyuap (Pasal 5 ayat (1) huruf a, 5 ayat (1) huruf $b, 13,5$ ayat (2), 12 huruf a, 12 huruf b, 11, 6 ayat (1) huruf a, 6 ayat (1) huruf b, 6 ayat (2), 12 huruf $c$, dan 12 huruf d), penggelapan dalam jabatan (Pasal 8, 9, 10 huruf a, 10 huruf $b$, dan 10 huruf c). Pemerasan (Pasal 12 huruf e, 12 huruf f, 12 huruf g), perbuatan curang (Pasal 7 ayat (1) huruf a, 7 ayat (1) huruf b, 7 ayat (1) huruf c, 7 ayat (1) huruf d, 7 ayat (2), dan 12 huruf h), benturan kepentingan dalam pengadaan (Pasal 12 huruf i), dan gratifikasi (Pasal 12 B jo. 12 C).

${ }^{8}$ Anwar Shah and Mark Schacter, 'Combating corruption: look before you leap', Finance \& Development, Vol. 41 (4/December), pp. 40-3
} 
Korupsi pada level grand corruption dan state capture adalah korupsi yang dilakukan secara sengaja, terrencana, berskala besar, dan melibatkan banyak fihak dari hulu ke hilir. Korupsi jenis ini biasanya dilakukan oleh segerombolan elit politik atau pejabat senior pemerintah yang membuat kebijakan atau peraturan untuk menguntungkan diri sendiri dan kelompok tertentu dengan memungkinkan mereka untuk menyalahgunakan sejumlah besar pendapatan dan fasilitas umum serta mendapatkan suap dari perusahaan nasional maupun transnasional. Sementara itu, 'state capture' atau 'regulatory capture', adalah korupsi yang dilakukan dengan memanfaatkan fasilitas, peraturan, atau sumber daya yang sudah ada, tanpa harus merencanakan dari hulu. Sedangkan 'bureaucratic corruption' adalah korupsi pada level pemerintahan terrendah. Hal ini biasanya dilakukan oleh pegawai negeri sipil yang menjadi pelaksana kebijakan pemerintah. Korupsi seperti ini biasanya terjadi pada titik pertukaran antara PNS dan warga negara atau kepada siapa mereka memberikan pelayanan publik secara langsung. Misalnya, terjadi pada layanan imigrasi, kepolisian, rumah sakit, pajak, sekolah, atau otoritas perizinan.

Selain itu, definisi korupsi juga bisa dilakukan dari perspektif konteks analisis yang digunakan. Perspektif itu bisa dikelompokkan menjadi tiga: public-office-centred, market-centred, dan public interest-centred. ${ }^{9}$ Teori public-office-centred, menggambarkan korupsi sebagai penyimpangan perilaku dari tugas-tugas normal pejabat publik atau pelanggaran terhadap aturan untuk melayani kepentingan pribadi, termasuk penyuapan, nepotisme, dan penyelewengan. Sedangkan teori market-centred, menggambarkan korupsi sebagai penyalahgunaan jabatan oleh pejabat publik dengan memonopoli kantor mereka dan proses membuat kebijakan (seperti pajak, subsidi, bahkan privatisasi) sebagai sarana memaksimalkan kepentingan diri mereka sendiri. Sementara teori public interest-centred, mendefinisikan korupsi sebagai tindakan seorang pemegang kekuasaan yang mengistimewakan siapa pun yang memberikan imbalan dan dengan demikian merusak prinsip persamaan (equality) dalam pelayanan masyarakat umum.

\footnotetext{
${ }^{9}$ Lihat Arnold J. Heidenheimer, Michael Johnston. and V.T. LeVine (eds), Political Corruption: A Handbook, New Brunswick, NJ: Transaction Publisher; lihat pula Collier, P. How to Reduce Corruption, Oxford: African Development Bank-Blackwell Publishers
} 
Akan tetapi, mengingat kompleksitas persoalan korupsi yang luas, teori-teori tersebut tidak selalu mampu untuk menggambarkan secara jelas tentang apa sebenarnya tindakan 'penyalahgunaan' atau 'penyelewengan'.10 Secara praktis, kerumitan terjadi dalam membedakan apa yang disebut sebagai kepentingan 'publik' dan 'pribadi'. Dalam sistem administrasi yang ruwet, sebagaimana beberapa studi kasus dalam penelitian ini, para pejabat bisa jadi melakukan berbagai inovasi dan kreatifitas penyelenggaraan pemerintahan untuk memenuhi kepentingan publik. Akan tetapi, inovasi tersebut dianggap melanggar hukum dan atau dinilai sebagai korupsi oleh aparatur pengak hukum.

Selain itu, keruwetan itu juga bisa terjadi karena pengaruh budaya. Di Eropa dan Amerika Utara pemberian hadiah dianggap sebagai salah satu wujud korupsi, tetapi tidak di kebanyakan negara Asia. Bahkan pemberian hadiah dianggap sebagai bentuk pemenuhan kewajiban 'kawula' kepada 'gusti'-nya. Dalam sebuah masyarakat yang berbudaya komunal dan berkonteks interaksi sosial tinggi (seperti di sebagian besar negara-negara Asia) ${ }^{11}$, membedakan kepentingan pribadi dengan kepentingan publik adalah suatu hal yang rumit. Sebagaimana di Korea, Jepang, dan juga Indonesia, karena adanya tradisi pemberian hadiah (gift giving), seseorang bisa jadi dianggap wajar secara budaya bila melakukan 'tindakan privat untuk kepentingan publik'. Sebagai contoh, masyarakat Jepang umumnya menoleransi politisi mereka menerima berbagai bentuk hadiah dari pelaku bisnis, dengan imbalan berupa kebijakan yang menguntungkan, asalkan hadiah itu dibagikan kepada konstituen mereka dan bukan untuk keuntungan individu. ${ }^{12}$ Dalam konteks tersebut, para politisi Jepang bisa jadi 'menyalahgunakan kekuasaan' bukan untuk 'kepentingan pribadi', tapi mungkin untuk kepentingan

\footnotetext{
${ }^{10}$ Michael Johnston, 'The Search for Definitions: The Vitality of Politics and the Issue of Corruption.' International Social Science Journal, Vol. 149 (Spring), h. 321-335 (English-language version).

11 Untuk melihat perspektif lebih lanjut tentang hal ini, kita bisa menggunakan teori Low Context and High Context Culture yang dikemukakan oleh Edward T. Hall (1973) dan dikembangkan lebih lanjut oleh Geert Hofstede (1993) dengan mendasarkan pada teori individual dan collectivism. Low context culture (budaya konteks rendah) terdapat pada masyarakat yang menganut budaya individual. Sedangkan High context culture (budaya konteks tinggi) terdapat pada masyarakat komunal. Budaya kenteks tinggi memiliki ciri berupa komunikasi yang cenderung tidak berterus terang untuk menjaga harmoni sosial, cenderung menyukai tata kelola secara kolektif, penilaian tentang 'baik' dinilai dari sudut pandang kelompok daripada individu, pemimpin dianggap sebagai 'big boss', dan 'saling memberi' dianggap sebagai pilar penting bagi terwujudnya kohesi sosial.

12 Susan Pharr 'Contributions, Covenants, and Corruption: Politicians and Society in Japan', in Michael Johnston and Kpundeh, S. R. (ed.), 'Building Social Action Coalitions for Reform', in Johnston, M. (ed.) Civil Society and Corruption: Mobilizing for Reform, Lanham, MD: University Press of America, pp. 23-32.
} 
'publik', yaitu konstituen mereka, dan budaya ini tidak dianggap sebagai tindakan korup. Demikian pula, Indonesia dengan pengaruh tradisi patronase yang kuat membuat semua property negara dapat digunakan sesuai dengan kehendak para pejabat sendiri. Di Indonesia, para pejabat dituntut oleh rakyatnya untuk menjadi 'sinterklas' atau 'bos' yang membagi bantuan ketika mereka berkunjung ke forumforum rakyat. Tidak heran, porsi anggaran untuk bantuan sosial (bansos) terkadang cukup besar di APBD berbagai daerah. Selain itu, dalam masyarakat Indonesia, kewajiban seseorang pertama-tama adalah memperhatikan saudara terdekatnya, kemudian trah atau sesama etniknya. Ada beban sosial yang melekat pada anggota keluarga yang dianggap sukses dalam hidupnya, sehingga seorang saudara yang mendatangi seorang pejabat untuk meminta perlakuan khusus sulit untuk ditolak. Penolakan bisa diartikan sebagai pengingkaran terhadap kewajiban tradisional. Akan tetapi, memenuhi permintaan berarti mengingkari norma-norma hukum formal yang berlaku. Akhirnya selalu terjadi konflik nilai, antara pertimbangan kepentingan keluarga atau kepentingan publik.

Dalam konteks ini, membandingkan prevelensi korupsi antar negara secara diametris adalah tidak mungkin. Tidak mengherankan kiranya, bahwa upaya untuk mengukur tinggi rendahnya korupsi dalam suatu negara, biasanya menggunakan pendekatan 'subyektif' dengan mempertimbangkan 'berapa banyak dan bagaimana tindakan yang korup itu berarti/berpengaruh bagi penduduk atau berbagai kelompok dari mereka'.13 Oleh karena itu, sejumlah survei korupsi menggunakan 'pendapat/persepsi orang' yang menilai terjadinya korupsi menurut penilaian mereka masing-masing. Sebagai contoh, survei Transparansi Internasional (TI) tentang Indeks Persepsi Korupsi (Corruption Perception Index, CPI) menyusun peringkat (tingkat) korupsi di berbagai negara dengan menanyakan persepsi pelaku bisnis di negara itu. Survei TI yang lain seperti Global Corruption Barometer (GCB) juga mengukur tindakan korupsi dengan menanyakan bagaimana orang-orang merasakan dampak korupsi.

Akan tetapi, beberapa ahli hukum ada yang berpendapat bahwa peraturan formal bisa menjadi kriteria standar untuk menentukan apa yang legal dan ilegal, dan apa yang bisa dan tidak merugikan kepentingan umum. Sebagaimana pendapat Fackler

\footnotetext{
${ }^{13}$ Michael Johnston 'The Search for Definitions'.
} 
\& Lin ${ }^{14}$, korupsi dapat didefinisikan sebagai salah satu dari 'berbagai tindakan melanggar hukum ... oleh aktor-aktor politik'. Oleh karena itu, Meier \& Holbrook ${ }^{15}$ berpendapat bahwa korupsi dapat diukur dalam periode sejarah tertentu dengan menghitung berapa pejabat publik yang dihukum di pengadilan negara. Sehingga menurut mereka, mendefinisikan korupsi berdasarkan hukum dan aturan formal lainnya diklaim sebagai cara terbaik dari perspektif presisi, stabilitas dan aplikasi yang luas.

Walau demikian, pendekatan para ahli hukum untuk menentukan tindakan korup juga dianggap tidak selalu tepat, khususnya di negara-negara dengan sistem hukum yang masih amburadul. Pejabat bisa menekankan aspek hukum dan mengabaikan substansi keadilan. Mereka melakukan sesuatu yang secara etis tidak benar tapi tetap bisa dinyatakan sah. Di beberapa negara Eropa Timur, pejabat bisa mengklaim perjalanan liburan pribadi sebagai studi banding. ${ }^{16}$ Sama halnya, diktator seperti Ferdinand Marcos di Filipina dan Soeharto di Indonesia dapat mengubah bagian-bagian peraturan negara untuk melegalkan tindakan mereka yang bersifat pribadi. Dengan demikian, peraturan tidak selalu berfungsi sebagai alat yang objektif, bahkan, sebagaimana dikatakan Sajo ${ }^{17}$ dan Collier ${ }^{18}$, dapat dijadikan alat untuk melegalkan korupsi. Sebaliknya, pejabat yang memiliki niat baik dapat terjerat hukum. Beberapa tindakan yang mungkin dianggap ilegal sebenarnya dapat dibenarkan secara moral. Sebagaimana dikemukakan Szeftel ${ }^{19}$, dalam negara dengan sistem manajemen publik yang buruk, pejabat negara harus berhadapan dengan pilihan menempuh prosedur birokrasi yang rumit, atau mereka mengabaikan peraturan tertentu, jika mereka harus mencapai tujuan yang menguntungkan kepentingan publik.

\footnotetext{
${ }^{14}$ Tim Fackler and Tse-min Lin 'Political corruption and presidential elections, 1929-1992', Journal of Politics, Vol. 57, pp. 971-93.

${ }^{15}$ Kenneth J. Meier and Thomas M. Holbrook 'I seen my opportunities and I took 'em: Political corruption in the American states' Journal of Politics, Vol. 54, pp. 135-55.

${ }^{16}$ Andras Sajo 'Introduction, Clientelism and Exortion' h. 3.

${ }^{17}$ Paul Collier How to Reduce Corruption, Oxford: African Development Bank-Blackwell Publishers.

18 ibid.

19 Morris Szeftel 'Between governance \& under-development: accumulation \& Africa's 'catastrophic corruption', Review of African Political Economy, Vol. 27 (84), h. 300.
} 
Terlepas dari kontroversi teori tersebut, korupsi bisa terjadi karena beberapa faktor. Menurut Bauhr dan Nasiritousi ${ }^{20}$, korupsi terjadi karena dua persoalan, yakni karena ada kebutuhan (corruption by need), dan karena sikap rakus untuk menumpuk kekayaan (corruption by greed). Korupsi karena sikap rakus (corruption by greed) biasanya terjadi ketika suap dalam skala besar diberikan untuk mendapatkan keuntungan pribadi. Sedangkan korupsi karena kebutuhan (corruption by need) biasanya terjadi pada layanan masyarakat, seperti pembuatan akta kelahiran atau perawatan kesehatan yang biasanya segera dikondisikan setelah membayar suap. Terdapat perbedaan pola relasi antara aktor yang terlibat dalam dua jenis korupsi ini. Korupsi karena keserakahan dibangun atas kolusi untuk saling menguntungkan, sementara korupsi karena kebutuhan dibangun di atas paksaan dan pemerasan. Korupsi karena sikap serakah biasanya kurang menonjol dibandingkan korupsi karena kebutuhan, karena lebih tersembunyi dan biaya korupsi dibagi-bagi antara sejumlah besar aktor dan pembayar pajak.

Berkaitan dengan penyebab korupsi, World Bank ${ }^{21}$ menyebutkan dua persoalan pokok, yaitu: (1) motivasi personal, dan (2) sistem yang buruk. Dalam konteks motivasi personal, orang melakukan korupsi supaya mendapatkan keuntungan secara tidak adil atas orang lain, misalnya menggelapkan sejumlah uang negara, supaya dapat membayar pajak yang lebih rendah, untuk mendapatkan kenaikan pangkat atau promosi, untuk memenangkan kontrak, atau untuk mendapatkan sesuatu yang dilakukan dengan cepat. Mereka mungkin juga menawarkan dan menerima suap untuk menghindari denda atau penalti. Orang melakukan korupsi untuk beberapa alasan khusus. Sebagai contoh, para politisi dan pejabat yang takut kehilangan jabatan mencari manfaat korup sebagai 'asuransi', terutama jika mereka tidak bisa mengharapkan pensiun, pejabat membutuhkan uang tambahan untuk mempertahankan standar hidup mereka jika gaji belum dinaikkan untuk mencocokkan inflasi, untuk memenuhi pembayaran kredit perumahan, mobil, biaya sekolah, dan sebagainya.

Sementara itu, di samping aspek individual sebagai alasan orang terlibat dalam korupsi, yang dianggap mencerminkan moralitas tentang orang-orang yang baik dan buruk, akan tetapi, sistem yang tidak bekerja dengan baik dan menciptakan insentif

\footnotetext{
${ }^{20}$ Monica Bauhr and Nagmeh Nasiritousi. Why Pay Bribes?

${ }^{21}$ World Bank. Youth for Good Governance, distance learning program (Module), Washington: World Bank.
} 
yang buruk juga dapat menjadi pendorong terjadinya kasus korupsi. Di level daerah, ada beberapa persoalan berkait dengan sistem yang buruk yang menyebabkan korupsi terjadi. Pertama, adanya kesempatan yang jelas, seperti 'segepok' uang tunai tergeletak di tempat umum. Desentralisasi politik dan fiskal dapat menyebabkan hal ini terjadi. Pejabat daerah memiliki kekuasaan dan diskresi yang besar untuk mengelola pemerintahan. Keadaan semacam ini bisa berbentuk pengelolaan APBD yang otonom, pengelolaan perusahaan yang dimiliki Pemerintah Daerah (Pemda) tanpa pesaing, atau daftar panjang dan biaya perijinan yang diperlukan untuk investasi. Kedua, rendahnya resiko untuk tertangkap. Hal ini diakibatkan karena akuntabilitas yang rendah, akibat kurangnya transparansi, dan atau juga lemahnya penegakan hukum karena rentang kendali operasional KPK yang jauh. Ketiga, insentif kerja yang buruk, seperti ketika pejabat politik atau pegawai Pemda tidak mendapatkan gaji yang cukup, sehingga melengkapi pendapatannya dengan suap. Keempat, sikap atau keadaan yang mengabaikan hukum. Keberadaan pedagang kaki lima ilegal misalnya akan dapat menjadi sumber korupsi berupa pungutan liar yang dilakukan oknum pejabat Pemda.

Badan Pengawasan Keuangan dan Pembangunan (BPKP) ${ }^{22}$ memberikan analisa yang lebih detil tentang penyebab korupsi diutarakan dalam buku berjudul Strategi Pemberantasan Korupsi pada Pengelolaan APBN antara lain:

\section{Aspek Individu Pelaku}

a. Sifat tamak manusia; Kemungkinan orang melakukan korupsi bukan karena orangnya miskin atau penghasilan tak cukup. Kemungkinan orang tersebut sudah cukup kaya, tetapi masih punya hasrat besar untuk memperkaya diri. Unsur penyebab korupsi pada pelaku semacam itu datang dari dalam diri sendiri, yaitu sifat tamak dan rakus.

b. Moral yang kurang kuat; Seorang yang moralnya tidak kuat cenderung mudah tergoda untuk melakukan korupsi. Godaan itu bisa berasal dari atasan, teman setingkat, bawahanya, atau pihak yang lain yang memberi kesempatan untuk itu.

c. Penghasilan yang kurang mencukupi; Bila gaji tidak cukup, seorang pegawai akan berusaha memenuhinya dengan berbagai cara, termasuk melakukan tindak

\footnotetext{
${ }^{22}$ BPKP, Upaya Pencegahan dan Penanggulangan Korupsi pada Pengelolaan APBN/APBD, BPKP: Jakarta. $\begin{array}{llllll}\text { [online, } & \text { diakses } & 12 & \text { Agustus } & 2016 & \text { dengan }\end{array}$ http://www.bpkp.go.id/public/upload/unit/investigasi/files/uppk_apbn_apbd(1).pdf]
} 
korupsi, baik itu korupsi waktu, tenaga, pikiran dalam arti semua curahan peluang itu untuk keperluan di luar pekerjaan yang seharusnya.

d. Kebutuhan hidup yang mendesak; Keterdesakan kebutuhan membuka ruang bagi seseorang untuk mengambil jalan pintas diantaranya dengan melakukan korupsi.

e. Gaya hidup yang konsumtif; Perilaku konsumtif yang tidak diimbangi dengan pendapatan yang memadai dapat mendorong seseorang untuk melakukan berbagai tindakan untuk memenuhi hajatnya, termasuk dengan tindakan korupsi.

f. Malas atau tidak mau kerja; Sifat malas potensial melakukan tindakan apapun dengan cara-cara melanggar hukum.

g. Ajaran agama yang kurang diterapkan. Semakin jauh seseorang dari agama, mereka semakin berani melakukan korupsi.

2. Aspek Organisasi

a. Kurang adanya sikap keteladanan pimpinan; Apabila pemimpin berbuat korupsi, maka kemungkinan besar bawahnya akan mengambil kesempatan yang sama dengan atasannya.

b. Tidak adanya kultur organisasi yang benar; Bila kultur organisasi tidak dikelola dengan baik, akan menimbulkan berbagai situasi yang koruptif.

c. Sistem akuntabilitas yang benar di instansi pemerintah yang kurang memadai; Ketidakjelasan visi dan misi menyebabkan sulit dilakukannya penilaian apakah instansi tersebut berhasil mencapai sasaranya atau tidak. Keadaan ini memunculkan situasi organisasi yang kondusif untuk praktik korupsi.

d. Kelemahan sistem pengendalian manajemen; Apabila pengendalian manajemen sebuah organisasi lemah, maka akan semakin terbuka perbuatan tindak korupsi anggota atau pegawai di dalamnya.

e. Manajemen cenderung menutupi korupsi di dalam organisasi; Sifat tertutup semacam ini menyebabkan pelanggaran korupsi justru terus berjalan dengan berbagai bentuk.

3. Aspek Tempat Individu dan Organisasi Berada 
a. Nilai-nilai di masyarakat kondusif untuk terjadinya korupsi Masyarakat yang menghargai seseorang karena kekayaan yang dimilikinya, seringkali membuat masyarakat tidak kritis pada kondisi, misalnya dari mana kekayaan itu didapatkan.

b. Masyarakat kurang menyadari sebagai korban utama korupsi. Mereka masih kurang menyadari bahwa merekalah yang menjadi korban kasus korupsi. Dianggap yang rugi adalah negara, padahal yang dirugikan adalah masyarakat juga karena proses anggaran pembangunan bisa berkurang.

c. Masyarakat tidak menyadari bila terlibat korupsi. Mereka seringkali terlibat dalam kegiatan korupsi dengan cara-cara terbuka namun tidak disadari.

d. Masyarakat tidak yakin bahwa korupsi akan bisa dicegah dan diberantas dengan peran serta masyarakat. Masyarakat umumnya berpandangan masalah korupsi itu tanggung jawab pemerintah.

e. Kelemahan dalam peraturan perundang-undangan. Peraturan perundangundangan yang monopolistik yang hanya menguntungkan kroni penguasa, kualitas peraturan yang kurang memadai, peraturan yang kurang disosialisasikan, sangsi yang terlalu ringan, penerapan sangsi yang tidak konsisten dan pandang bulu, serta lemahnya bidang evaluasi dan revisi peraturan perundang-undangan.

\section{Upaya Pemberantasan Korupsi}

Mengingat kasus korupsi pada tingkat daerah masing-masing memiliki kekhasan tertentu, maka upaya pemberantasannya memerlukan rekognisi dan investigasi terhadap variabel yang berpengaruh pada daerah tersebut. Oleh karenanya, kita perlu memahami pola, sifat dan kontur korupsi di daerah tertentu sebagai dasar untuk menyusun strategi antikorupsi yang dirancang dengan baik. Kita juga perlu menganalisis kecenderungan dan kemampuan pihak-pihak terkait dalam pemberantasan korupsi seperti pejabat, masyarakat sipil dan komunitas bisnis. Hal tersebut tentu bukan tugas yang mudah.

Terlebih, faktor yang berpengaruh tidak secara eksklusif hanya berada pada daerah itu sendiri. Temuan World Bank ${ }^{23}$ di banyak negara berkembang, korupsi di

\footnotetext{
${ }^{23}$ Maria Gonzales de Aziz, Reducing Corruption at the local level, h. 2.
} 
tingkat lokal tidak bisa lagi dilihat sebagai jumlah kasus yang terisolasi. Masalahnya telah menyebar dan menjadi sistemik sebagai bagian dari persoalan sistem pemerintahan secara nasional. Tata kelola pemerintahan yang tidak baik pada level nasional, dapat berpengaruh terhadap kekacauan pemerintahan di tingkat lokal. Oleh karena itu, analisis untuk lebih memahami penyebab dan sifat korupsi perlu dilakukan dalam perspektif yang luas, multi level pemerintahan, multi dimensional, dan multi sektoral.

Sejalan dengan hal tersebut, dalam Development as Freedom, Amartya Sen ${ }^{24}$ berpendapat bahwa tiap individu, untuk mencapai potensi mereka, harus bebas dari dominasi sosial-politik sepihak dan harus menggabungkan sumber daya mereka untuk mengejar kepentingan mereka bersama secara kolektif dan menyediakan barangbarang publik untuk banyak orang. Tentu saja jelas, bagaimanapun, bahwa tujuan kebebasan adalah untuk mendistribusikan sumber daya publik secara sama dan adil untuk semua orang. Walaupun demikian, kebebasan dan demokrasi tidak selalu menghasilkan rezim pemerintahan yang berdasar pada universalisme etis. Elit, klan, suku, partai politik, dan kelompok dominan lain mungkin sebenarnya menggunakan kebebasan mereka untuk mendapatkan kepentingan sempit mereka sendiri daripada orang-orang dari masyarakat luas.

Oleh karena itu, kebijakan anti-korupsi pada prinsipnya adalah strategi untuk mengurangi korupsi secara nasional dan menjadi satu paket strategi yang komprehensif untuk menyusun langkah-langkah guna meningkatkan transparansi dan akuntabilitas pemerintahan. Selain strategi anti-korupsi, beberapa negara juga memperkenalkan pendekatan korupsi yang difokuskan secara sektoral (seperti pendidikan, kesehatan, dan pelayanan air) melalui pembuatan skala prioritas yang berdasarkan pada penilaian risiko. Atau, dalam beberapa kasus, ada pula negara-negara (seperti Australia, misalnya) yang melakukan strategi anti-korupsi tidak secara langsung melalui penindakan, melainkan mempromosikan upaya yang lebih luas untuk meningkatkan transparansi dan akuntabilitas. Berbeda dengan kebijakan strategi anti-korupsi konvensional yang secara eksplisit berlabel "anti-korupsi", langkah-langkah integritas

${ }^{24}$ Amartya Sen, Development as freedom (1st ed.). New York: Oxford University Press 
tersebut mungkin terlihat lebih implisit karena mereka tertanam ke sistem governance (tata pemerintahan yang lebih luas) dan program reformasi peradilan.

Banyak penelitian tentang korupsi, terutama yang ditulis oleh para ekonom, mengadopsi pendekatan "principal-agent": Mereka mendalilkan adanya keberadaan "principal" (kepala) yang setiap saat bermaksud baik yang kepercayaan disalahgunakan oleh beberapa "agen" dan yang diasumsikan memiliki minat untuk melawan korupsi. Jadi bantuan untuk program good-governance biasanya diarahkan untuk para "principal" tersebut (kementerian, lembaga pengawas, dan badan-badan antikorupsi), yang dianggap secara moral di atas korupsi.

Namun sayangnya, mereka yang memiliki kekuatan paling diskresioner justru memiliki peluang paling besar untuk bertindak korup. Mereka dapat menempatkan pejabat pemerintah tingkat tinggi dan legislator dalam posisi terbaik untuk memanipulasi lembaga antikorupsi atau untuk mempengaruhi kebijakan dan perundang-undangan yang mendukung kelompok-kelompok kepentingan tertentu. Akibatnya, lebih sering daripada tidak, "principal" tersebut justru berfungsi sebagai pelindung atau penjaga pintu untuk tindak kejahatan korupsi, atau bahkan sebagai pelaku (capo di tutti capi) korupsi yang sebenarnya. ${ }^{25}$

Dalam konteks ini, pengalaman berbagai negara menunjukkan bahwa strategi anti-korupsi lebih mudah diterapkan ketika mereka diletakkan dalam inisiatif pembangunan nasional yang lebih luas. Integrasi ini ke dalam rencana pembangunan nasional telah terbukti sebagai cara yang efektif untuk mendorong kerjasama lintas instansi dari awal dan menghindari pendekatan sempit dalam mempromosikan pembangunan manusia. Misalnya di Malaysia, anti-korupsi adalah salah satu capaian utama nasional yang merupakan usaha yang ditempuh melalui Program Transformasi Pemerintah (Government Transformation Programme), yang bertujuan untuk memberikan kontribusi dalam membuat Malaysia sebagai negara berpenghasilan tinggi sesuai Visi 2020.

Yang paling penting, upaya pengukuran korupsi tidak cukup hanya menggunakan monitoring dan evaluasi terhadap strategi anti-korupsi. Pada umumnya

\footnotetext{
${ }^{25}$ Alina Mungiu Pippidi 'Controlling Corruption Through Collective Action, Journal of Democracy, Volume 24, Number 1, pp. 101-115.
} 
digunakan juga alat pengukuran seperti survei korupsi, penilaian integritas / indeks korupsi, dan studi diagnostik kelembagaan. Survei korupsi digunakan untuk mengumpulkan persepsi, pengalaman, dan pandangan dari masyarakat umum, pengusaha, dan pejabat publik. Namun, mereka dapat digunakan dengan cara yang lebih sistematis untuk memantau pelaksanaan strategi anti-korupsi.

Tantangannya adalah lembaga anti korupsi yang diberi tanggungjawab untuk membuat dan melaksanakan stategi yang komprehensif dalam skala nasional. Dua faktor bisa menjelaskan persoalan yang membuat negara berkembang kadang kesulitan dalam implementasi, monitoring, dan evaluasi strategi pemberantasan korupsi. Pertama, pelaksanaan strategi terletak pada beberapa instansi dalam pemerintahan membuat koordinasi sangat sulit. Di samping itu, lembaga anti-korupsi, yang diharapkan untuk melakukan tugas pelaksanaan, monitoring dan evaluasi, seringkali tidak memiliki cukup sumber daya dan kekuatan untuk melakukannya. Kedua, apabila strategi anti-korupsi menetapkan tanggung jawab keseluruhan untuk pelaksanaan pada lembaga khusus seperti Komisi Pemberantasan Korupsi (KPK), pemusatan kewenangan ini kadang tidak disertai sumberdaya dan wewenang yang diperlukan untuk menuntut tindakan dari kementerian kuat. ${ }^{26}$ Lembaga anti-korupsi ini kadang bergantung kepada lembaga lain dalam memenuhi kebutuhan sumberdaya manusia (pegawai, penyelidik) kepada instansi lain seperti kepolisian dan kejaksaan, sebagaimana kasus KPK di Indonesia.

Namun, memberantas korupsi bukanlah tujuan akhir. Memberantas korupsi adalah perjuangan melawan ketidakberesan dalam pemerintahan, dan merupakan bagian dari tujuan yang lebih luas, yakni menciptakan pemerintahan yang efektif, adil, dan efisien. Untuk memulai upaya pemberantasan korupsi, titik tolaknya adalah memahami terlebih dahulu sebab-sebab, celah-celah, dan berbagai insentif yang menimbulkan keinginan untuk melakukan tindakan korupsi di tingkat mana saja, termasuk di daerah.

\section{Kasus Korupsi di Daerah}

Sebagaimana dikemukakan di atas, korupsi di daerah dipengaruhi oleh kontekstualitas daerah yang bersangkutan. Tetapi, terdapat pula benang merah tentang pola dan modus korupsi di daerah yang hampir mirip satu sama lain.

\footnotetext{
${ }^{26}$ Jeremy Pope, Confronting Corruption: The Elements of a National Integrity System, Berlin: Transparency International
} 
Indonesia Corruption Watch (ICW) mengungkapkan, modus korupsi paling banyak terjadi di sepanjang tahun 2015 berupa penyalahgunaan anggaran. Berdasarkan temuan ICW, di peroleh 134 kasus dengan nilai kerugian negara sebesar Rp 803,3 miliar. Salah satu kasus penyalahgunaan anggaran yang terbesar adalah korupsi dana bansos yang dilakukan Bupati Bengkalis Herliyan Saleh. Korupsi tersebut merugikan negara sebesar Rp 29 miliar. Selain modus penyalahgunaan anggaran, modus lain yang sering digunakan adalah modus penggelapan sebanyak 107 kasus dengan nilai kerugian negara sebesar Rp. 412,4 miliar, modus mark up sebanyak 104 kasus dengan nilai kerugian negara sebesar Rp. 455 miliar dan penyalahgunaan wewenang sebanyak 102 kasus dengan nilai kerugian negara sebesar Rp. 991,8 miliar. Sementara modus korupsi lain, namun dengan jumlah yang kecil, seperti laporan fiktif sebanyak 29 kasus, suap atau gratifikasi sebanyak 24 kasus, proyek fiktif sebanyak 20 kasus, pemotongan sebanyak 15 kasus, pemerasan sebanyak 6 kasus, mark down sebanyak 5 kasus, pungutan liar 3 kasus dan satu kasus anggaran ganda (Kompas, 24 Februari 2016). ${ }^{27}$

Secara umum, menurut ICW, terdapat empat modus korupsi yang dapat ditemukan di hampir semua kasus. Modus pertama adalah mark up, mark down, laporan fiktif, penyalahgunaan wewenang, dan penggelapan. Mark up dilakukan pada pembiayaan atau pengeluaran anggaran dengan menaikkan jumlah pengeluaran yg seharusnya, untuk kepentingan pribadi, sehingga negara dirugikan. Sedangkan modus mark down dilakukan pada pengelolaan pendapatan daerah. Misalnya, potensi pendapatan yang ada sebenarnya besar, namun dalam perencanaan pendapatan dilakukan penurunan nilai potensi yang ada. Dalam laporan realisasi pendapatan daerah pun nilai yang dilaporkan sering tidak sesuai dengan realisasi sebenarnya.

Modus kedua adalah menggandakan (redundant) item penerimaan melalui berbagai strategi. Strategi yang paling kerap muncul adalah memasukkan item anggaran yang berbeda-beda untuk satu fungsi. Misalnya terdapat pos asuransi untuk kesehatan, tapi di pos lain muncul item tunjangan kesehatan. Padahal kedua pos penerimaan tersebut untuk satu fungsi, yakni anggaran bagi kesehatan anggota Dewan. Strategi lain adalah menitipkan pos penerimaan itu pada anggaran eksekutif (Pemda). Biasanya item

\footnotetext{
${ }^{27}$ http://nasional.kompas.com/read/2016/02/24/17044021/ICW.Sepanjang.Tahun.2015.Anggaran.Negara.134.Ka li.Dikorupsi.
} 
anggaran itu disebut sebagai bantuan untuk instansi vertikal seperti yang terjadi dalam kasus dana kapling di Jawa Barat.

Modus ketiga adalah mengada-adakan pos penerimaan anggaran yang sebenarnya tidak diatur dalam PP Nomor 110/2000. Kasus yang paling banyak mencuat dan digugat oleh berbagai elemen masyarakat adalah alokasi anggaran untuk pos dana purnabakti. Di Jawa Barat, dana purnabakti lebih populer dengan istilah uang kadeudeuh. Selain dana purnabakti, fasilitas rumah dinas yang seharusnya hanya diberikan kepada ketua dan wakil ketua DPRD ternyata digelontorkan untuk semua anggota Dewan.

Modus keempat adalah korupsi dalam pelaksanaan program kegiatan. Dari aspek tindakan, korupsi jenis ini adalah korupsi yang paling telanjang dan nyata. Ini sebagaimana telah dilakukan oleh anggota DPRD Kota Padang yang telah memalsukan tiket pesawat perjalanan dinas (SPJ fiktif) hingga mencapai Rp 10,4 miliar.

Di antara keempat modus korupsi tersebut, modus keempat bisa dianggap yang paling konvensional dan umum terjadi di berbagai instansi pemerintah daerah. Dalam pengertian tindakan korupsi dengan cara memanipulasi dokumen pertanggungjawaban penggunaan APBD hingga seolah-olah sebuah program telah dilaksanakan merupakan perbuatan yang nyata-nyata melanggar hukum, merugikan keuangan negara, dan terdapat upaya untuk memperkaya diri sendiri. Sementara itu, modus korupsi yang pertama hingga ketiga merupakan produk kesepakatan dua pihak (eksekutif dan legislatif) dengan memanfaatkan dua hal, kewenangan yang dimiliki untuk membuat peraturan dan celah perundang-undangan yang tumpang-tindih.

Korupsi model ini dianggap seolah-olah bukan merupakan tindakan korupsi karena telah dinaungi dalam sebuah peraturan daerah (Perda) yang legal. Padahal, dari sisi materi peraturan, banyak terdapat penyimpangan, baik terhadap peraturan yang lebih tinggi maupun dari aspek normatif lainnya seperti rasa keadilan, kepantasan umum, atau kelaziman. Karena dipayungi dalam bentuk peraturan, korupsi jenis ini sering disebut sebagai korupsi yang dilegalkan atau legalisasi korupsi. Mengingat legalisasi penyimpangan didasari kesepakatan dua pihak pengelola daerah, korupsi yang telah menyeret beratus-ratus pejabat publik ini sebenarnya tidak bisa dilepaskan 
dari keterlibatan dan tanggung jawab pihak eksekutif (baca: kepala daerah). Secara garis besar, modus korupsi dapat disimpulkan seperti pada tabel berikut.

Tabel 1 Modus Korupsi di Daerah

\begin{tabular}{|c|c|c|c|}
\hline & Konvensional & $\begin{array}{c}\text { Political } \\
\text { Corruption }\end{array}$ & $\begin{array}{c}\text { State Capture } \\
\text { Corruption }\end{array}$ \\
\hline Modus & $\begin{array}{l}\text { SPPD } \\
\text { Tiket dan } \\
\text { program fiktif } \\
\text { Mark-up } \\
\text { proyek }\end{array}$ & $\begin{array}{l}\text { Penjarahan } \\
\text { APBD } \\
\text { Bansos }\end{array}$ & $\begin{array}{l}\text { Pembuatan } \\
\text { kebijakan yang } \\
\text { dibuat koruptif }\end{array}$ \\
\hline Aktor & $\begin{array}{ll}\text { - } & \text { Birokrat } \\
\text { - } & \text { Penegak } \\
& \text { hukum } \\
\text { - } & \text { Kontraktor }\end{array}$ & $\begin{array}{ll}\text { - } & \text { Birokrat } \\
\text { - } & \text { Makelar/ } \\
\text { timses } \\
\text { - } & \text { Pengurus } \\
& \text { parpol } \\
\text { - } & \text { Anggota } \\
& \text { DPRD } \\
\text { - } & \text { Pejabat } \\
& \text { eksekutif }\end{array}$ & $\begin{array}{ll}\text { - } & \text { Birokrat } \\
\text { - } & \text { Makelar/ } \\
& \text { timses kepala } \\
& \text { daerah } \\
\text { - } & \text { Pengurus } \\
& \text { parpol } \\
\text { - } & \text { Anggota DPRD } \\
\text { - } & \text { Pejabat } \\
& \text { eksekutif }\end{array}$ \\
\hline
\end{tabular}

Sumber: diadopsi dari ICW (2015) dan beberapa sumber lain.

\section{B. PEMBAHASAN}

\section{Empat Studi Kasus}

Penelitian ini berusaha menggambarkan kontekstualitas empat studi kasus korupsi yang pelakunya berhasil kami wawancarai. Kasus-kasus tersebut menggambarkan variasi penyebab dan jenis korupsi yang terjadi di daerah. Keempat studi kasus tersebut adalah:

\section{Kasus Walikota A}

A adalah seorang mantan walikota yang memiliki latarbelakang sebagai pengusaha. Menurut penjelasan yang bersangkutan dalam wawancara, sebelum menjabat walikota, A memiliki kehidupan yang cukup mapan dengan istri dan seorang anak. A mengklaim bahwa dia sebenarnya sudah hidup berkecukupan dan tidak kekurangan materi. Dia menyatakan menjadi politisi (anggota DPRD dua kali dan kemudian menjadi walikota) karena panggilan ingin memperbaiki keadaan kotanya dan tidak berniat memperkaya 
diri sendiri. Bahkan, A menyatakan bahwa selama menjabat Walikota, dirinya harus banyak 'tombok' (mengeluarkan uang pribadi) untuk kepentingan kantor. Akan tetapi, mengingat background dia sebagai pengusaha, A menyatakan tidak memiliki pengetahuan yang memadai sebagai kepala daerah.

Mantan Wali Kota A dijatuhi vonis oleh Pengadilan Tindak Pidana Korupsi (Tipikor) karena dinyatakan bersalah atas kasus korupsi dana bantuan sosial (bansos) untuk pedagang Pasar GR Kota G tahun 2007. Pada tanggal 30 Oktober 2013, Majelis Hakim menjatuhkan hukuman 2 tahun enam bulan penjara dan denda sebesar Rp 50 juta atau setara 2 bulan penjara bersama Kepala DPKAD. Kedua terdakwa dianggap terbukti secara sah dan meyakinkan melakukan korupsi secara bersama-sama. Kedua terdakwa dinyatakan melanggar dakwaan subsidair jaksa penuntut umum. Yakni Pasal 3 Undang-undang (UU) Nomor 31 tahun 1999 sebagaimana telah ditambahkan dalam UU Nomor 20 tahun 2001 Jo pasal 55 ayat (1) ke-1 KUHP.

Menurut hakim, kedua terdakwa terbukti mencairkan dana bantuan sosial (bansos) dengan menyalahi aturan. Dana yang dicairkan tersebut semestinya disalurkan pada pedagang untuk subsidi uang muka pembelian kios dan los Pasar GR yang telah dibangun. Jumlah anggaran sebesar Rp 2,8 miliar seharusnya dicairkan saat pembangunan pasar mencapai 100 persen. Namun saat pasar yang dibangun baru mencapai 51 persen, dana bantuan pedagang itu sudah dicairkan. A mendalilkan bahwa hal itu dilakukan karena terpaksa untuk menanggulangi keresahan masyarakat akibat kontraktornya tidak punya uang untuk menyelesaikan pekerjaan. Pada saat itu, para pedagang gelisah karena mereka tidak dapat segera berdagang di pasar karena pekerjaan yang tertunda. Sebagaimana dia katakan:

Nah ini kan karena pemborongnya nggak punya duit, hutang sana hutan sini, hutang ke Pemda juga.. Semua pihak tahu, sekda tahu. DPRD diam saja. Tapi saya merasa ini tanggungjawab saya..

(kasus) pasar gotong royong ini sebetulnya kan ya demi kenyamananlah supaya masyarakat tenang, pedagang tenang ya karena ingin pengerjaannya tepat waktu, lha ini segala upaya saya laksanakan biar tepat waktu karena pemborongnya kan tahu-tahu nggak punya duit lah pemborongnya itu, hutang sana hutang sini. Nah terus upaya saya ini yang kena, bantuan subsidi seharusnya dicairkan setelah proyek selesai, nah ini saya bagi per prosentase paralel dengan prosentase pekerjaan, $60 \%$ apa berapa bantuan saya cairkan senilai $60 \%$ dari total 3,5 M saya cairkan 2,8 M, nah ini yang jadi masalah. Posisinya pasar baru jadi 60\%. Yang 
dicairkan 2.8 M, karena pemborongnya nggak punya duit, ijin bangunan kan juga belum dibayar itu, untuk pemindahan pedagang dari pasar ke penampungan itu juga ada biayanya dll ini totalnya $1,7 \mathrm{M}$. Sehingga mikir saya dapet $60 \%$ itu cair 2,8 $\mathrm{M}$ tapi yang $1 \mathrm{M}$ tidak saya berikan ke investor, ini yang jadi masalah (Wawancara dengan A, 15/06/2016).

Pencairan dilakukan atas nota dinas A yang ditindaklanjuti oleh Kepala DPKAD dengan menerbitkan surat perintah pencairan dana. Dana yang sudah cair kemudian ditampung di rekening Bendahara Pembantu sebelum disalurkan. Menariknya, akan tetapi, pada persidangan tidak ditemukan adanya aliran dana pada para terdakwa. Artinya walikota A maupun Kepala DPKAD tidak menerima uang dari kasus tersebut. Sebab itu, majelis hakim tidak menjatuhkan hukuman tambahan berupa uang ganti rugi untuk negara. Tidak heran kiranya, A menilai kasus yang dia alami sebenarnya bukan perkara korupsi, tetapi semata-mata kesalahan administrasi. Sebagaimana dia katakan:

Sulit bagi saya untuk merasa adil. Kecuali kalau saya benar-benar merugikan Negara, saya terima. Saya hanya membantu untuk mencairkan uang muka demi berjalannya kontrak sesuai dengan waktu. Masalahnya hanya waktu pembayaran, waktu pencairan dana itu (Wawancara dengan A, 15/06/2016).

Dengan demikian, walikota A ini berada pada posisi dan pilihan kebijakan yang dilematis: pada satu sisi harus meredam keresahan rakyat (para pedagang), pada sisi lain, bila itu dilakukan, dia melanggar aturan prosedur pencairan dana. A memilih pilhan yang pertama, walaupun kemudian berakibat dirinya terkena perkara hukum.

\section{Kasus Walikota B}

B adalah mantan walikota yang juga berasal dari keluarga sangat terpandang dan kaya raya di kotanya. Menurut penuturan $B$, keluarganya memiliki aset usaha ratusan milyar. B sendiri adalah anak ke empat dan laki-laki tertua dari enam bersaudara yang dipercaya keluarganya untuk menjalankan usaha. Dalam wawancara, B menyatakan bahwa penghasilannya tiap bulan telah mencapai puluhan kalau tidak ratusan juta, jauh melebihi penghasilannya sebagai walikota.

Mantan Wali Kota B, dijatuhi hukuman lima tahun penjara dalam kasus dugaan korupsi tukar guling (ruislag) lahan milik Pemerintah Kota (Pemkot). Hukuman yang dijatuhkan Pengadilan Tindak Pidana Korupsi (Tipikor) pada Selasa 11 Agustus 2014. B dinyatakan bersalah telah menyalahgunakan wewenangnya sebagai Walikota dalam proses ruislag lahan milik Pemkot dengan pihak swasta. Majelis hakim juga 
menjatuhkan hukuman denda sebesar Rp 300 juta setara dengan hukuman kurungan selama tiga bulan. Hakim menyatakan B terbukti bersalah melanggar pasal 3 Undangundang Nomor 31 tahun 1999 yang telah diubah dengan Undang-undang Nomor 20 tahun 2001 tentang pemberantasan tindak pidana korupsi.

Majelis hakim juga menjatuhkan pidana tambahan kepada B berupa pengembalian uang pengganti kerugian negara sebesar Rp 350 juta. Uang Rp 350 juta tersebut diterima terdakwa berkaitan dengan proses tukar guling yang diduga sebagai suap. Menurut hakim, perbuatan terdakwa yang telah menyalahgunakan wewenang dan jabatannya sebagai Wali Kota dalam perkara ini telah merugikan keuangan negara. Proses tukar guling lahan tersebut dinilai menguntungkan dua perusahaan swasta, didasarkan atas nilai tanah yang berdasarkan perhitungan ahli terdapat selisih yang menyebabkan terjadi kerugian negara. Hakim menilai ada rangkaian kerja sama yang sudah diskenariokan sebelumnya untuk menguntungkan CV TD, PT COM, Hj R, serta terdakwa sendiri.

Kasus B bermula dari adanya kebutuhan TPA (Tempat Pembuangan Akhir) sampah yang lebih besar bagi kotanya. TPA yang lama sudah tidak bisa menampung sampah warga kota yang terus bertambah. Akan tetapi, tidak ada dana APBD untuk pembelian lahan bagi TPA baru, sehingga walikota B berinisiasi untuk dilakukan tukar menukar dengan pihak swasta. Menurut B, kebijakan seperti ini sebenarnya masuk dalam kebijakan diskresi walikota dengan syarat tidak melakukan kerugian Negara, sesuai dengan Permendagri 17/200728. Yang menjadi permasalahan adalah adanya persepsi BPK bahwa tukar guling itu terlalu murah sehingga ditemukan kekurangan bayar sebesar Rp. 1,2 M yang kemudian dipersoalkan oleh kejaksaan. Kekurangan tersebut kemudian dibayar oleh pihak investor sehingga penyelidikan dihentikan. Putusan tersebut ternyata tidak memuaskan kalangan LSM, sehingga mereka

\footnotetext{
${ }^{28}$ Permendagri tersebut mengatur Pedoman Teknis Pengelolaan Barang Milik Daerah, yang dalam Pasal 6 Ayat 1 disebutkan bahwa: Kepala Daerah sebagai pemegang kekuasaan pengelolaan barang milik daerah, mempunyai wewenang: a. menetapkan kebijakan pengelolaan barang milik daerah; $b$. menetapkan penggunaan, pemanfaatan atau pemindahtanganan tanah dan bangunan; c. menetapkan kebijakan pengamanan barang milik daerah; d. mengajukan usul pemindahtanganan barang milik daerah yang memerlukan persetujuan Dewan Perwakilan Rakyat Daerah; e. menyetujui usul pemindahtanganan dan penghapusan barang milik Daerah sesuai batas kewenangannya; dan $\mathrm{f}$. menyetujui usul pemanfaatan barang milik daerah selain tanah dan/atau bangunan.
} 
melaporkan kasus tersebut ke pihak KPK. Setelah dilakukan penyelidikan, KPK menilai adanya indikasi korupsi sebesar $8 \mathrm{M}$, bukan sekedar 1,2 M.

Dengan demikian, ada perbedaan penafsiran antar institusi penegak hukum, yakni kejaksaan dan KPK. Hal ini dinilai B menyebabkan adanya ketidakpastian hukum. Sebagaimana dia katakan:

Antara lembaga satu dengan yang lain prosedur yang ada tidak memiliki kepastian. Jadi karena SKUP yang kemudian tidak memiliki kepastian, maka siapapun akan menjadi kuat ketika mengalami hal yang sama. Bagaimana penyelenggara Negara melakukan penilaian yang secara logika dasar sudah tidak memenuhi syarat.... Pertanyaannya dimana kerugian Negara? Bagaimana membandingkan harga tanah sawah dengan tanah daratan? Yang saya masih belum terima bagaimana cara membandingkan harga tanah yang dipermasalahkan. (Wawancara dengan B, 16/06/2016).

\section{Kasus Birokrat Senior C}

C adalah seorang Kepala Dinas di suatu Kabupaten. C divonis pidana penjara 3 tahun dan juga dibebani denda Rp 500 juta atau setara enam bulan kurungan oleh Majelis hakim Pengadilan Tipikor. C dinyatakan terbukti bersalah terkait kasus proyek pemeliharaan jalan di Kabupaten Z tahun 2009-2010 senilai Rp 2,4 miliar. Dia didakwa menyalahgunakan anggaran sewaktu menjadi pejabat pembuat komitmen atau kepala program dalam proyek tersebut.

Dalam dakwaan subsider, C didakwa bersalah melanggar ketentuan Pasal 3 jo Pasal 18 UU Nomor 31 Tahun 1999 sebagaimana diubah dan diganti menjadi UU Nomor 20 Tahun 2001 jo Pasal 55 Ayat 1 ke-1 KUHP. Hakim menyatakan bahwa seluruh unsur yang termuat dalam pasal terpenuhi. Unsur itu, antara lain tiap orang menguntungkan diri sendiri atau orang lain, menyalahgunakan kewenangan, dan merugikan keuangan negara. Kasus terjadi pada saat yang bersangkutan menjadi Kabid, terdakwa dengan kekuasaannya melakukan penunjukan langsung rekanan penyedia jasa. Rekanan hanya dimintai tanda tangan tanpa mengikuti lelang. Meski demikian, rekanan justru mendapat pembayaran melalui rekening perusahaan. Uang itu kemudian diserahkan kepada terdakwa.

Proyek pemeliharaan jalan di Kabupaten Z sendiri tersebar ke berbagai kecamatan di kabupatennya. Total paket pengerjaan pada tahun 2009 sebanyak 56 
paket kerjaan, 16 paket tidak dikerjakan. Pada tahun 2010, ada 29 paket pekerjaan yang tidak dikerjakan. Meski tak dikerjakan, uang pembayaran tetap dibayarkan sehingga Pemkab Z merugi miliar rupiah. Rinciannya, tahun 2009 merugi Rp 1,067 miliar dan tahun $2010 \mathrm{Rp}$ 1,655 miliar. Total Rp 2,426 miliar. Jumlah kerugian inilah yang kemudian ditimpakan kepada terdakwa untuk dimintakan pembayaran.

Terdakwa menerima uang dari rekanan yang tak melakukan lelang. Terdakwa didakwa menikmati uang sejumlah Rp 2,4 M. Meski nyatanya digunakan pembelian material, tapi dilakukan sendiri, bukan dilakukan oleh rekanan. Selain $\mathrm{C}$, perkara ini juga menyeret anak buah D, seorang Kabid, Subbagian Umum dan kepegawaian, Kepala UPT Kecamatan, dan rekanan pelaksana proyek.

\section{Kasus Birokrat Senior D}

D adalah mantan Kepala Dinas Kabupaten B yang divonis tiga tahun dan enam bulan kurungan dalam sidang perkara dugaan korupsi dana bantuan sosial (bansos) Jaringan Irigasi tahun 2011 yang diilai merugikan negara Rp 659 juta di Pengadilan Tipikor, pada 27 Juni 2014. Selain itu D juga dikenakan denda Rp 50 juta subsider dua bulan oleh majelis hakim. D diputus bersalah karena dianggap turut serta melakukan tindak pidana korupsi sesuai pasal 3 Undang-Undang (UU) Nomor 31/ 1999 sebagaimana diubah dalam UU Nomor 20 Tahun 2001 tentang Pemberantasan Tindak Pidana Korupsi.

Ironisnya, menurut hakim, D tidak sepeser pun terbukti menikmati uang dari kerugian negara. Walau demikian, D dianggap telah menyalahgunakan kewenangan dengan tidak mematuhi prosedur penentuan petani/ kelompok tani selaku penerima manfaat dana bansos pertanian. Penentuan penerima manfaat tidak dilakukan melalui seleksi tim teknis yang sebelumnya diusulkan terdakwa. Kelompok penerima manfaat juga tidak semuanya membuat proposal, RAB (rancanangan anggaran biaya-red), dan gambar desain. Selaku penanggung jawab pengelolaan dana bansos pertanian, terdakwa hanya memenuhi penerima manfaat sesuai permintaan terpidana lain yang juga wakil ketua DPRD Kabupaten B. Adapun, tim teknis yang dibentuknya justru dibiarkan.

Sebagaimana diceritakan yang bersangkutan, kasus yang menimpa D sesungguhnya tidak lepas dari konteks setting persaingan politik dalam Pilkada. Sejak tahun 2009 D adalah seorang kepala dinas, dan pada tahun 2011 diselenggarakan Pilkada di kabupatennya. D menyatakan diri sebagai seorang Kepala Dinas yang netral, 
tidak mau terlibat dalam Pilkada dalam membantu salah satu calon. Oleh karena itu, Tim sukses Bupati terpilih menyatakan dia adalah 1 di antara 2 kepala dinas yang harus keluar dari pemerintahan, dengan alasan bahwa dia bukan merupakan bagian barisan bupati terpilih. Dalam perkembangannya, akan tetapi, ada seorang ketua partai pendukung Bupati (sebut saja E) yang meminta secara pribadi kepada Bupati agar D tetap dipertahankan sebagai kepala dinas pertanian dengan alasan profesionalitas. E kebetulan adalah ketua partai sekaligus wakil ketua DPRD. Tim sukses yang lain merasa keberatan bila D dipertahankan. Dengan demikian, D tetap menjadi kepala dinas tapi dengan kondisi yang penuh konflik. Setiap saat, pihak yang tidak mau terima D selalu membuat berbagai manuver yang menjatuhkan D.

Selanjutnya, D diberikan tugas untuk mengamankan visi- misi Bupati yang ingin mengembangkan pertanian. Untuk itu Dinas Pertanian menjadi SKPD prioritas. Konsep pembangunan pertanian yang dijanjikan Bupati dalam kampanye harus diimplementasikan. Dalam kaitan itu, kabupaten memerlukan dukungan anggaran dari pemerintah pusat maupun instansi lain yang terkait. Gayung bersambut, karena kebetulan ketua komisi 4 DPR RI yang membidangi pertanian adalah dari partai E, dan berasal dari Dapil 7 yang termasuk kabupaten B. Sehingga terjadilah komunikasikomunikasi by pass antara ketua komisi 4 DPR, ketua partai kabupaten, bupati, D dan E. Banyak anggaran dana dari pemerintah pusat yang mengalir ke kabupaten B. D harus memfasilitasi implementasi proyek-proyek pertanian itu secara teknis, tanpa mengetahui dinamika politik yang detail. D kemudian menyusun tim teknis untuk membantu fasilitasi proyek. Ketua komisi 4 sekaligus ketua partai sering ke kabupaten untuk menkomunikasikan semuanya. Ketemu dengan kader-kader mereka. Sehingga ada simbiosis mutualisme antara anggota dewan dengan konstituennya. D tidak menyadari bahwa ada transaksi tertentu antara partai dengan para kelompok tani yang menjadi penerima bantuan. Sebagaimana dinyatakan oleh D:

Saya tidak melihat ada transaksi-transaksi politik di luar itu. Ternyata political point yang terjadi luas sekali, tidak sekedar apa yang terlihat dan apa yang ada di atas kertas... Jadi ada transaksi antara anggota dewan dengan kelompok tani, dan kita nggak paham itu, kita nggak ketahui (Wawancara dengan D, 15/06/2016).

Kasus yang diperkarakan kepada D adalah proyek irigasi tahun 2011 di kabupatennya yang dialokasikan kepada 79 kelompok tani dengan nilai total Rp 4 miliar. Besaran nilai proyek rata-rata 50 juta per kelompok. Dana tersebut merupakan hibah dari 
Kementerian pertanian dan langsung masuk ke rekening kelompok tani. Setelah dana proyek cair, ada orang mengaku tim teknis yakni PR (mantan pegawai Dinas Pertanian) dan LA, mendatangi kelompok-kelompok tani dan memungut uang antara Rp 8 juta sampai Rp 10 juta/kelompok dengan jumlah pungutan seluruhnya sekitar Rp 600 juta. Uang tersebut diklaim untuk disetorkan ke anggota DPRD, dalam pengadilan hal ini tidak dijelaskan anggota DPRD ini siapa. D sendiri terbukti tidak menerima aliran dana dari pungutan ini. Akan tetapi pengadilan tetap menghukum yang bersangkutan dengan dalih ikut bekerjasama dalam kasus korupsi, memperkaya orang lain.

\section{Lesson Learn: Penyebab, Modus, dan Faktor yang berperan dalam Korupsi}

Banyaknya kasus korupsi yang dilaporkan dan dibongkar sesungguhnya merupakan sebuah bukti bahwa masyarakat sudah geram dengan penyalahgunaan kekuasaan. Praktik korupsi, kolusi, pemborosan, kesewenang-wenangan, serta tindakan tidak etis yang melanggar nilai-nilai umum dipertontonkan secara berulang-ulang. Syed Hussein Alatas (dalam Sumarwani S. 2011), mengemukakan beberapa ciri-ciri korupsi dengan menyebutnya sebagai suatu pengkhianatan terhadap kepercayaan (betrayal of trust), dimana seseorang diberikan amanah sebagai seorang pemimpin, tetapi menyalahgunakan wewenangnya untuk kepentingan pribadi, golongan, atau kelompoknya. Korupsi juga bisa dicirikan dengan adanya penipuan terhadap badan pemerintah, lembaga swasta, atau masyarakat umumnya.

Faktor penyebab seseorang melakukan tindakan korupsi yaitu faktor dorongan dari dalam diri sendiri (keinginan, hasrat, kehendak, dan sebagainya) dan faktor rangsangan dari luar (misalnya dorongan dari teman-teman, kesempatan, kurang kontrol dan sebagainya). Setiap saat korupsi bisa berubah menjadi buas dan rakus, tak kenal batas, sehingga siap meluluhlantakkan segala nilai moral-spiritual, dan tak lagi mengenal nilai-nilai tanggung jawab pada kepentingan umum, kejujuran, kebenaran, keadilan, pemerataan, disiplin diri, rasa hemat, dosa, dan sebagainya.

Penelitian ini, menemukan bahwa sesungguhnya tidak semua kasus korupsi di daerah, setidaknya dari perspektif pelaku, berkaitan dengan keinginan untuk memperoleh kekayaan atau motif penghianatan terhadap kepercayaan (betrayal of trust). Sebagian dari mereka, memang terbukti melakukan korupsi untuk secara sengaja memperkaya diri sendiri atau orang lain. Akan tetapi, ada juga kasus-kasus dimana para 
pelaku tidak menikmati hasil korupsi, melainkan karena berada pada posisi yang serba salah. Mereka memasuki jabatan publik juga dengan motivasi yang tidak berkaitan dengan keinginan untuk menyalahgunakan kekuasaan atau penghianatan terhadap kepercayaan yang diberikan.

Mereka pada umumnya terjebak dalam kasus korupsi karena ketidaktahuan terhadap batasan-batasan pengertian korupsi. Hal ini dapat dimaklumi, karena tidak ada pelatihan, pembekalan, maupun pendidikan yang memadai bagi mereka tentang korupsi sebelum mereka menjabat. Kesempatan yang mereka miliki untuk belajar ketika mereka menjabat, khususnya bagi pejabat politik, juga sangat terbatas. Sebagai contoh adalah kasus yang dialami oleh Walikota B:

saya sebenarnya tidak berpikir untuk menjadi politisi karena latarbelakang saya swasta dan sudah memiliki penghasilan cukup besar. Saya tertarik menjadi walikota hanya ingin memperbaiki kota saya supaya lebih baik. Akan tetapi dunia birokrasi dan bisnis memang ternyata sangat berbeda, sementara tidak cukup waktu untuk saya mempelajari semua urusan. (Wawancara dengan B, $15 / 06 / 2015)$

Sebagian dari mereka justru memiliki keinginan melakukan improvisasi dalam manajemen publik yang secara sadar atau tidak sadar menabrak peraturan yang ada. Beberapa diantara pejabat yang diwawancarai mengemukakan bahwa mereka justru ingin menolong masyarakat, dan memberikan jalan keluar atas kebuntuan dalam persoalan penyelenggaraan negara dan pelayanan publik. Sebagaimana dikemukakan oleh salah seorang informan tentang kasus yang dia hadapi:

(kasus) pasar gotong royong ini sebetulnya kan ya demi kenyamananlah supaya masyarakat tenang, pedagang tenang ya karena ingin pengerjaannya tepat waktu, lha ini segala upaya saya laksanakan biar tepat waktu karena pemborongnya kan tahu-tahu nggak punya duit lah pemborongnya itu, hutang sana hutang sini (Wawancara dengan A, 15/06/2015)

Dengan demikian, bila dilihat dari perspektif teori public centered interest, kasus seperti yang dialami walikota tersebut bukanlah kasus korupsi, karena publik justru mendapatkan kemanfaatan dari kasus yang dia lakukan.

Selanjutnya, temuan penelitian ini memperlihatkan, bahwa sesungguhnya tidak semua pihak yang ikut menjadi tersangka kasus korupsi adalah pihak yang ikut menikmati hasil korupsi itu. Beberapa diantara mereka menjadi korban konspirasi dan 
tidak tahu menahu tindak kejahatan yang dilakukan orang lain yang menyeret mereka dalam kasus tersebut. Mereka terlibat hanya gara-gara menjadi orang yang kebetulan berada pada posisi dan waktu yang salah. Orang yang mengalami nasib seperti ini biasanya adalah birokrat yang menjadi pelaksana kebijakan, yang tidak bisa menghindar dari tekanan politik.

Kasus yang dialami oleh D dapat menjadi contoh kasus yang menarik. Dia adalah seorang kepala dinas pertanian yang daerahnya mendapatkan proyek dari pemerintah pusat. Dalam pelaksanaannya, ada anggota tim teknis bekerjasama dengan oknum partai politik yang memanfaatkan kegiatan proyek itu untuk mendapatkan keuntungan pribadi (dan atau kelompok). Mereka memungut uang dari kelompok-kelompok tani yang mendapatkan hibah bantuan dari proyek tersebut untuk kepentingan partai politik tertentu. Dalam pengadilan, tidak ada bukti bahwa D menerima aliran dana pungutan itu. Akan tetapi pengadilan tetap menghukum yang bersangkutan dengan dalih ikut bekerjasama dalam kasus korupsi, memperkaya orang lain. D sesungguhnya berada pada posisi yang dilematis karena harus memilih diantara resiko yang berat. Bila dilaksanakan dia bisa mendapat imbas dari penyelewengan pihak lain (yakni partai politik), tapi bila tidak dilaksanakan, $\mathrm{F}$ akan mendapatkan protes dari kelompok tani, pimpinan (bupati), maupun koleganya di DPRD.

Temuan lain dari hasil penelitian di lapangan adalah berkaitan dengan keruwetan administrasi pemerintahan. Pelaku merasa terjebak dalam keruwetan persoalan penyelenggaraan pemerintahan yang dirasa tidak memberikan ruang dan kewenangan yang cukup untuk menjalankan tugas. Seperti yang dinyatakan oleh salah satu narasumber sebagai berikut:

Dalam kasus saya, saya menilai ini hanya kesalahan administrasi, tidak ada kerugian negara, terkait tanggungjawab jabatan saya (Wawancara dengan $\mathrm{B}$, 15/06/2016).

Dalam hal ini, UU No. 20 Tahun 2001 tentang Pemberantasan Tindak Pidana Korupsi pasal 3 menyebutkan "setiap orang yang dengan tujuan menguntungkan diri sendiri atau orang lain atau suatu korporasi, menyalahgunakan kewenangan, kesempatan, atau sarana yang ada padanya karena jabatan atau kedudukan yang dapat merugikan keuangan negara atau perekonomian negara..”. Dalam pasal tersebut terdapat unsur penyalahgunaan kewenangan dan kesempatan atau sarana yang ada 
pada birokrat karena jabatan atau kedudukannya merupakan bagian dari tindakan korupsi. Namun, seperti yang dinyatakan oleh B, ia menilai perbuatannya sebagai kesalahan administrasi dan tidak masuk dalam ranah korupsi karena tidak ada kerugian negara yang ditimbulkan.

Ada dua kategori yang sangat berbeda mengenai korupsi administrasi (Pope, 2000: 8). Pertama, korupsi terjadi dalam situasi, misalnya, jasa atau kontrak diberikan 'sesuai peraturan yang berlaku', dan kedua, korupsi terjadi dalam situasi transaksi berlangsung secara 'melanggar peraturan yang berlaku'. Dalam situasi pertama, seorang pejabat mendapat keuntungan pribadi secara ilegal karena melakukan sesuatu yang memang sudah kewajibannya untuk melaksanakan sesuai dengan undang-undang. Dalam situasi kedua, 'pelanggaran' dilakukan demi mencapai tujuan pelayanan publik, atau mendapatkan pelayanan dari pejabat yang menurut undang-undang dilarang memberikan pelayanan yang bersangkutan. Korupsi 'sesuai peraturan yang berlaku' dan korupsi 'melanggar peraturan yang berlaku' dapat terjadi pada semua tingkat hirarki pemerintahan dan berkisar dari sisi jumlah dan dampak, dari korupsi akbar hingga korupsi kecil-kecilan.

Terkait dengan esensi kerugian negara dalam pemberantasan korupsi, sebagian besar narasumber menganggap bahwa mereka seharusnya tidak bisa dijerat dengan pasal korupsi karena tidak ada kerugian negara yang ditimbulkan dari perbuatannya. Mereka berdalih bahwa tindakan tersebut merupakan bagian dari tanggung jawab jabatan yang diembannya. Faktor-faktor yang mengurangi kemauan seorang pejabat publik untuk mengambil tindakan adalah salah satunya karena keyakinan bahwa perilaku bersangkutan dapat dibenarkan dalam situasi bersangkutan dan bukan merupakan tindakan korupsi. Salah satu narasumber mengatakan demikian:

Saya didakwa terkait kasus pencairan dana. Dana ini saya cairkan sebelum proyek selesai karena kontraktor kehabisan dana... Saya berbuat demi kelancaran, keamanan dan demi kesejahteraan masyarakat. Apapun saya lakukan, tapi sekarang tidak bisa, kenyataannya saya dinyatakan bersalah padahal proyeknya terlaksana dengan baik, semuanya tercapai dengan baik (Wawancara dengan A, 15/06/2016).

Dari keterangan di atas, para pejabat itu secara individu bisa jadi tidak memiliki keinginan untuk bertindak korup, akan tetapi mereka terpaksa terlibat dalam tindakan korupsi karena sistem administrasi tidak memungkinkan mereka bertindak bersih. 
Peraturan yang berbelit-belit dan tidak jelas, hierarkhi organisasi yang terlalu kaku, dan tugas yang terlalu luas, untuk menyebut beberapa contoh, dapat menyebabkan seorang pejabat terjebak dalam tindakan yang dipersepsikan sebagai korupsi. Wewenang mengambil keputusan berdasarkan pertimbangan pribadi dalam batas-batas tertentu dalam birokrasi diperlukan untuk membangun administrasi yang efektif. Seperti yang disebutkan oleh salah satu narasumber:

Menurut saya, selalu ada faktor kebijakan (wisdom) seorang pemimpin dalam pelaksanaan birokrasi agar tujuan dari agenda birokrasi tercapai. Akan tetapi, terkadang kebijakan yang dilakukan birokrat tidak terangkum dalam peraturan yang ada, yang kemudian dituduh sebagai penyalahgunaan wewenang, korupsi, dan sebagainya (Wawancara dengan G, 16/05/2016).

Akan tetapi, sepertinya terjadi kesalahan persepsi tentang apa yang dimaksud dengan faktor kebijaksanaan pemimpin (wisdom). Seharusnya wisdom memiliki keterkaitan pemaknaan dengan esensi tercapainya kepentingan rakyat yang hakiki (misalnya berkaitan dengan konteks kesejahteraan, kemakmuran, ketenteraman, ketertiban, dan keadilan). Akan tetapi, aparat penegak hukum kadang terlalu melihat wisdom dalam arti yang sempit, yakni ketaatan terhadap hukum formal belaka.

Kinerja aparat penegak hukum sendiri memang masih dipandang buruk oleh publik. Ketidakpercayaan yang besar pada integritas penegak hukum dalam menjalankan kewajibannya menegakkan hukum dapat dilihat dari berbagai survei beberapa tahun terakhir. Yang terbaru, lebih dari separuh masyarakat, menurut survei yang digelar Indo Barometer pada akhir September 2015, menyatakan tidak puas atas kinerja lembaga penegak hukum, terutama kejaksaan dan kepolisian selama satu tahun pemerintahan Presiden Joko Widodo-Wakil Presiden Jusuf Kalla (Tempo, 23 April 2015).

Bagaimana kinerja aparat penegak hukum ini di mata para terpidana kasus korupsi? Sebagian dari mereka menyatakan tidak puas dengan kinerja yang tidak profesional. Misalnya berkaitan dengan penegakan hukum yang berjalan sangat lamban, standar SOP dan penafsiran yang berbeda-beda, bahkan penuh dengan 'permainan' antara aparat yang menangani dengan pelaku, atau penetapan hukum tanpa memperhatikan norma sosial yang menghilangkan makna hakikinya. Ini artinya penegakan hukum justru menciptakan adanya ketidakpastian hukum. Bila ada satu jenis tindak pidana yang sama tetapi memiliki konsekwensi hukum yang berbeda, karena 
beda penafsiran antar aparat penegak hukum sendiri, maka hukum menjadi sangat subyektif dan justru melemahkan semangat pemberantasan korupsi. Salah seorang informan menyatakan:

saya hanya menyayangkan adanya perbedaan perhitungan dan SOP seperti ada perbedaan dan ketidakcocokan antara lembaga satu dengan lainnya (Wawancara dengan C, 15/06/2016)

Jika beroroentasi pada konsep sosial keadilan, orang melanggar hukum seharusnya dilihat dari perbuatan dan motifnya. Selama ini yang kita alami adalah perbuatan saja yang dilihat tapi tidak dilihat motif atau konteksnya. Apakah yang seperti itu adil? Sekarang ini, esensi dari korupsi adalah tentang kerugian negara, tapi di banyak kasus tidak ada uang negara yang diambil, dan kami masih dituduh melakukan korupsi (Wawancara dengan D, 15/06/2016).

Celakanya sampai sekarang, mempersoalkan tanggung gugat peradilan masih dianggap tabu. Belum ada mekanisme yang cukup jelas yang mengatur hal ini, misalnya seperti yang disebutkan oleh salah satu narasumber:

Jika hukum merupakan cerminan dari keadilan, maka seharusnya dibersihkan dulu aparat penegak hukum yang adalah bagian dari pemegang kekuasaan. Mereka tidak bisa berbuat semena-mena. Sampai sekarang, tidak ada satu mekanisme pun yang bisa kita gunakan untuk menunjukkan bahwa jaksa itu salah karena tidak bisa menunjukkan tuntutannya dan juga jika hakim salah karena tidak berbuat adil (Wawancara dengan G, 16/04/2015).

Dengan demikian, menjadikan pemberantasan korupsi tidak efektif dan justru menjadikan persoalan tersebut menjadi semakin tidak bisa tertangani dengan baik.

\section{PENUTUP}

Hasil penelitian ini menunjukkan bahwa desentralisasi masih menyisakan masalah yang berkaitan dengan adminisitrasi pemerintahan yang ruwet, peraturan yang berbelit-belit dan tidak jelas, serta tata kelola kepentingan politik yang tidak terlembagakan secara formal. Kesemua hal tersebut dapat menyebabkan seorang pejabat daerah terjebak dalam tindakan yang dipersepsikan sebagai korupsi. Kondisi ini diperparah oleh lemahnya perilaku dan komitmen aparat penegak hukum dalam pemberantasan korupsi.

Kasus korupsi yang banyak terjadi di daerah, tidak dipertanyakan lagi, memerlukan penanganan yang serius dan berkesinambungan. Akan tetapi, penanganan 
yang tidak tepat bukan hanya akan membuat persoalan tidak teratasi, melainkan juga membuat keadaan menjadi semakin memburuk. Bahkan juga akan menggoncangkan sendi-sendi penyelenggaraan pemerintahan dan pelayanan publik. Ketidakpastian penegakan hukum akan membuat pejabat di tingkat pusat maupun di tingkat daerah, takut membuat keputusan karena khawatir kalau keputusannya itu kemudian bisa berdampak merugikan negara, dianggap menyalahgunakan wewenang atau menguntungkan orang lain, diri sendiri, korporasi dan sebagainya.

Akibat dari hal tersebut dapat meliputi berbagai persoalan baru yang rumit dan berefek domino. Pertama, inisiatif untuk melakukan kreatifitas penyelenggaraan pemerintahan daerah, dan menciptakan terobosan-terobosan menjadi sangat minim. Pejabat daerah lebih memilih bekerja untuk cari aman, melakukan seremoni, text book, dan tidak melakukan upaya penyelesaian masalah rakyat, apalagi yang menyangkut keuangan negara yang cukup besar. Pada level birokrat dan administrasi, menyebabkan tidak ada pegawai yang mau jadi pimpinan proyek, atau pejabat pembuat komitmen, mengingat tanggung jawabnya besar, berresiko masuk penjara, sementara gaji yang diterima tidak ada perbedaan yang signifikan dengan pegawai lainnya.

Kedua, tidak heran kiranya, semakin lama realisasi penggunaan anggaran daerah sangat rendah, sisa anggarannya akan banyak. Sementara, program-program dan kegiatan diarahkan kepada hal yang memiliki resiko ringan, seperti pelatihan dan sosialisasi. Dalam situasi seperti ini, usaha reformasi birokrasi juga menjadi sia-sia. Birokrat yang dituntut untuk bekerja secara kreatif-inovatif menjadi tidak memiliki keberanian mengambil keputusan. Sehingga, kita juga menjadi sulit berharap bila standar pelayanan publik itu sama dengan standar pelayanan swasta.

Ketiga, penyerapan anggaran yang rendah mengakibatkan rendahnya pertumbuhan ekonomi. Infrastruktur tidak tersedia dengan baik, sementara tidak adanya stimulus kegiatan ekonomi dari APBN/D menyebabkan pengangguran dan kemiskinan tidak bisa teratasi.

Keempat, sektor publik atau penyelenggara negara akan senantiasa jauh tertinggal dibandingkan dengan sektor swasta. Instansi pemerintah daerah akan sulit bersaing dengan swasta apalagi dengan perusahaan luar negeri. 
Walaupun demikian, kita juga tetap tidak boleh mengabaikan fakta adanya potensi korupsi di daerah yang bersifat kriminal murni karena maksud dan motivasi yang jahat dari para pejabatnya. Bagaimanapun, sektor ini mempekerjakan jutaan orang, memiliki anggaran yang besar, dan terlibat dalam jutaan transaksi setiap minggu. Para pejabat daerah menikmati kekuasaan diskresi yang cukup besar dan monopoli atas pelayanan publik seperti kesehatan, pendidikan, perumahan, pengelolaan tanah, penyediaan air dan penanganan limbah. Tingginya proses birokrasi yang dikombinasikan dengan interaksi lebih dekat pada titik pelayanan dapat memberikan kesempatan untuk korupsi, suap dan pemerasan. Struktur kekuasaan lokal, afiliasi partai dan jaringan sosial, dikombinasikan dengan banyaknya poin interaksi antara masyarakat dan sektor swasta, memberikan latar belakang yang beragam untuk memungkinkan terjadinya korupsi.

Oleh karena itu, beberapa saran yang perlu diperhatikan untuk memperbaiki hal tersebut adalah:

1) Dibuat formulasi alternatif kebijakan pemberantasan korupsi yang komprehensif berdasarkan pada asas akuntabilitas dan partisipasi publik. Kebijakan tersebut tidak semata-mata menekankan punishment, melainkan juga reward.

2) Penilaian terhadap suatu persoalan sebagai "korupsi" hendaknya mengacu kepada definisi substantif, yakni "memperkaya diri sendiri dan atau orang lain secara tidak sah", bukan semata-mata melihat kesalahan administratif dan prosedur.

3) Para pejabat hendaknya diberikan kelaluasaan dalam melakukan tata kelola pemerintahan dan pelayanan publik. Mereka harus diberikan ruang untuk melakukan inovasi dan kreatifitas tanpa mendapatkan ketakutan akan resiko mendapatkan tuduhan korupsi. Sepanjang mereka dapat memperlihatkan tujuan hakikinya untuk kepentingan rakyat.

4) Pembekalan dan pelatihan anti korupsi hendaknya diberikan kepada para pembuat kebijakan, setidaknya pada para pejabat pembuat komitmen dan para pejabat kuasa pengguna anggaran. Hal ini penting agar supaya mereka tidak terjebak dalam area yang mereka tidak faham.

\section{DAFTAR REFERENSI}

Bauhr, Monica and Nagmeh Nasiritousi. 2011, Why Pay Bribes? Collective Action and Anti Corruption Efforts, Sweden: University of Gothenburg. 
BPKP, Upaya Pencegahan dan Penanggulangan Korupsi pada Pengelolaan APBN/APBD, BPKP: Jakarta. [online, diakses 12 Agustus 2016 dengan alamat http://www.bpkp.go.id/public/upload/unit/investigasi/files/uppk apbn apbd(1).pdf]

Collier, Paul. 2000, How to Reduce Corruption, Oxford: African Development BankBlackwell Publishers.

Fackler, Tim and Tse-min Lin, 1995, 'Political corruption and presidential elections, 1929-1992', Journal of Politics, Vol. 57, pp. 971-93.

Gonzales de Aziz, Maria, 2006, Reducing Corruption at the local level, World Bank Institute, [online, diakses 12 Nopember 2016, alamat: http://siteresources.worldbank.org/WBI/Resources/ReducingCorruptionattheLocalLevel.pdf]

Hall, Edward T. 1973. The silent language, Garden City, N.Y: Anchor Press/Doubleday.

Heidenheimer, Arnold J., Michael Johnston and V.T. LeVine (eds), 1989, Political Corruption: A Handbook, New Brunswick, NJ: Transaction Publisher; lihat pula Collier, P. How to Reduce Corruption, Oxford: African Development Bank-Blackwell Publishers

Hofstede, Geert. 1993. Hofstede, G. J. 1993. 'Cultural constraints in management theories' In J. T. Wren (Ed.), The leader's companion (pp. 253-270). New York: Free Press.

Johnston, Michael. 1996, 'The Search for Definitions: The Vitality of Politics and the Issue of Corruption.' International Social Science Journal, Vol. 149 (Spring), pp. 321-335 (English-language version).

Meier, Kenneth J., and Thomas M. Holbrook, 1992, 'I seen my opportunities and I took 'em: Political corruption in the American states' Journal of Politics, Vol. 54, pp. 135-55.

Pharr, Susan. 1989, 'Contributions, Covenants, and Corruption: Politicians and Society in Japan', in Michael Johnston and Kpundeh, S. R. (ed.), 'Building Social Action Coalitions for Reform', in Johnston, M. (ed.) Civil Society and Corruption: Mobilizing for Reform, Lanham, MD: University Press of America, pp. 23-32.

Pippidi, Alina Mungiu. 2013, 'Controlling Corruption Through Collective Action, Journal of Democracy, Volume 24, Number 1, pp. 101-115.

Pope, Jeremy. 2000, Confronting Corruption: The Elements of a National Integrity System, Berlin: Transparency International.

Rose-Ackerman, Susan. 1978, Corruption: A Study in Political Economy, New York: Academic Press.

Sajo, Andras. 2002, 'Introduction, Clientelism and Exortion: Corruption in Transition' in Kotkin, S. and A. Sajo (eds), Political Corruption in Transition: A Skeptic's Handbook, Budapest: Central Europe University Press, pp. 1-24

Sen, Amartya. 1999, Development as freedom (1st ed.). New York: Oxford University Press

Shah, Anwar and Mark Schacter, 2004, 'Combating corruption: look before you leap', Finance \& Development,Vol. 41 (4/December), pp. 40-3 
Szeftel, Morris. 2000, 'Between governance \& under-development: accumulation \& Africa's 'catastrophic corruption', Review of African Political Economy, Vol. 27 (84), h. 300 .

Transparency International, 2013, Corruption in UK Local Government, The Mounting Risks [online, diakses 14 Nopember 2016, alamat: http://sro.sussex.ac.uk/52109/1/Corruption in UK Local Government- The Mounting Risks.pdf]

World Bank. 2003. Youth for Good Governance, distance learning program (Module), Washington: World Bank. 